\title{
Mandated disclosures under IAS 36 Impairment of Assets and IAS 38 Intangible Assets: Value relevance and impact on analysts' forecasts
}

Paul André

Dionysia Dionysiou

Ioannis Tsalavoutas*

May, 2017

Accepted for publication in Applied Economics published by Taylor and Francis.

We gratefully acknowledge helpful comments received from two anonymous reviewers, Barbara Davidson, Mark Clatworthy, Richard Martin, Francesco Mazzi, Michael Stewart and the participants of the $16^{\text {th }}$ Financial Reporting and Business Communication Conference (Bristol, July 2012). Thanks to Yin Wang and Michael Mavromatis for excellent research assistance. We also thank the Association of Chartered Certified Accountants (ACCA), the Carnegie Trust for the Universities of Scotland, the ESSEC KPMG Financial Reporting Centre and the Accounting and Finance Division at the University of Stirling for funding this study.

* Corresponding author.

Paul André is at HEC Lausanne (UNIL, CH-1015, Lausanne, Switzerland. E-mail address: paul.andre@unil.ch).

Dionysia Dionysiou is at The University of Stirling (Stirling Management School, Accounting and Finance Division, FK9 4LA, Scotland, UK. E-mail address: Dionysia.Dionysiou@ @stir.ac.uk).

Ioannis Tsalavoutas, is at The University of Glasgow (Adam Smith Business School, West Quadrangle, Gilbert Scott Building, Room G683, University Avenue, Glasgow, G12 8QQ, Scotland, UK. E-mail adress: Ioannis.Tsalavoutas@ glasgow.ac.uk). 


\title{
Mandated disclosures under IAS 36 Impairment of Assets and IAS 38 Intangible Assets: Value relevance and impact on analysts' forecasts
}

\begin{abstract}
Drawing on a large sample of European firms, we examine whether variant compliance levels with mandated disclosures under IAS 36 Impairment of Assets and IAS 38 Intangible Assets are value relevant and affect analysts' forecasts. Our results indicate a mean (median) compliance level of about $84 \%$ (86\%) but high variation among firms; and disclosure levels regarding IAS 36 being much lower than those regarding IAS 38. In depth analysis reveals that non-compliance relates mostly to proprietary information and information that reveals managers' judgment and expectations. Furthermore, we find a positive (negative) relationship between average disclosure levels and market values (analysts' forecast dispersion). Results, however, hold more specifically for disclosures related to IAS 36, and these also improve analysts' forecast accuracy. Our findings add knowledge regarding the economic consequences of mandatory disclosures, have an appeal to regulators and financial statement preparers, and reflect on the IASB's concerns to increase the guidance and principles on presentation and disclosure.
\end{abstract}

Keywords: Mandatory disclosures, value relevance, analysts' forecasts, intangibles, impairments, IAS 36, IAS 38.

JEL Classifications: M40, M41, M48, G10 


\section{Introduction}

Following on from the Post-Implementation Review of IFRS 3 Business Combinations (PIR), the International Accounting Standards Board (IASB) has added to its research agenda several issues, including whether changes should be made to the existing impairment test for noncurrent, non-financial assets, including goodwill and the extent to which other intangible assets should be separated from goodwill. In order to take this decision, the Board took into consideration inter alia evidence from academic literature and other reports (IASB, 2015). This prior work, first, indicates that the extent of mergers and acquisitions has significantly increased the importance of intangible assets and goodwill in firms' financial statements as a result of the requirements of IFRS 3 on acquisition (FRRP, 2006, p.4). ${ }^{1}$ Second, it has been consistently reported that there was an underlying issue of non-compliance with the disclosures mandated by IAS 36 Impairment of Assets and IAS 38 Intangible Assets during the early years of IFRS mandatory adoption by EU listed firms (see FRRP, 2006; the European Commission, 2008; the ICAEW; 2007; the SEC, 2007; and Company Reporting Ltd, 2007; 2008). Beyond this, there is heated debate from standard setters and professional bodies about the usefulness of the disclosures mandated by accounting standards in general and intangible assets in particular (see for example IASB's public Disclosure Forum in January 2013; EFRAG 2012; ICAS and NZICA 2011; Hans Hoogervorst's speech on 'Breaking the boilerplate' in July 2013). The most recent development in the area is the IASB's 'Disclosure Initiative' and the recent Discussion Paper on the Principles of Disclosures. ${ }^{2}$

\footnotetext{
${ }^{1}$ For example, an Ernst \&Young (2009) study of over 700 deals that took place in 2007 indicates that, on average, $23 \%$ of the deal values were allocated to identifiable assets, whilst close to $50 \%$ was allocated to goodwill. Tsalavoutas et al. (2014: 21) report that the mean (median) percentage of goodwill recognised over the purchase price is $54 \%(51 \%)$ for a sample of large international firms reporting under IFRS in 2010.

${ }^{2}$ http://www.ifrs.org/Current-Projects/IASB-Projects/Disclosure-Initiative/Pages/Disclosure-Initiative.aspx http://www.ifrs.org/Current-Projects/IASB-Projects/Disclosure-Initiative/Principles-ofDisclosure/Pages/Exposure-Draft-and-Comment-letters.aspx
} 
On reflection of this background and following prior studies (e.g., Mazzi et al., 2017; Glaum et al., 2013b; Tsalavoutas, 2011), in this study, we focus on the first year of the implementation of the revised IFRS 3 and on the two standards the debate from standard setters focuses on i.e., IAS 36 and IAS 38. More specifically, we first hand collect data and calculate the compliance score with the mandatory disclosure requirements of IAS 36 and IAS 38 for a sample of 373 listed companies from European countries in 2010/11. Considering that complying with the standards' mandatory disclosure requirements implies disclosure of relevant information, we subsequently explore the value relevance of these compliance/disclosure levels as well as their relationship with analysts' forecast accuracy and dispersion. Evidence in the relevant literature on this subject is absent. Thus, we provide evidence on the topic which is on standard setters' agenda but also contribute to the accounting literature which calls for evidence regarding the valuation implications of mandatory disclosures (cf. Hassan et al., 2009; Leuz and Wysocki, 2016; Bushee and Leuz, 2005; Kang and Pang, 2005).

Our results can be summarised as follows. The mean (median) level of compliance scores for our sample firms is $83.9 \%(85.7 \%)$ and significant variability in these scores is identified (standard deviation of $13.4 \%)$. The mean (median) compliance for IAS 36 is $81.9 \%(85.7 \%)$ and for IAS 38 is $85.9 \%$ (90\%). The standard deviation of the compliance score for IAS 36 is $18.9 \%$ and for IAS 38 is $15.5 \%$. Even though the companies in our sample are among the largest in their country, there is a fairly large number of companies with compliance levels below $80 \%$ (131 for IAS 36 and 78 for IAS 38). In fact, minimum scores are as low as zero regarding IAS 36 and $33.3 \%$ for IAS 38.

To shed more light on these results, we report the specific paragraphs for which frequent non-compliance (i.e., less than $90 \%$ compliance) is observed. These include assumptions and estimations used in the application of value in use calculations; the amounts of impairment 
losses across reportable segments; the amount of intangible assets allocated to cash generating units; and the reasons for designating an intangible asset with indefinite useful life. Variation in this kind of information is particularly important for the purposes of our study given that it reflects the concerns highlighted in the literature about the information content of intangible assets as well as the implementation quality of the impairment tests.

Finally, we find that the average disclosure levels are positively value relevant and reduce analysts' forecast dispersion. In fact, when testing for the disclosure levels of each standard separately, we find that these results are driven mostly by the disclosure levels regarding IAS 36. Accordingly, these findings indicate that increased levels of compliance with IAS 36 imply more transparent financial statements (Pownall and Schipper, 1999) and that greater transparency of information mitigates uncertainty about company fundamentals (Anctil et al., 2004).

The remainder of the paper is organised as follows. Section 2 discusses the relevant literature and the rationale of the study, leading to the research hypotheses. Section 3 describes the data and the research design employed. Section 4 provides the empirical findings and section 5 concludes.

\section{Background and hypotheses development}

\subsection{Background: relevance and faithful representation}

A primary focus of the IASB and other standard setters is equity investment. Thus, the qualitative characteristics of relevance and faithful representation of financial statements are of most importance. It is commonly agreed that an item is relevant if it is capable of making a difference to financial statement users' decisions (IASB, Conceptual Framework 2010, QC6). Additionally, 'financial reports represent economic phenomena in words [emphasis added] and numbers. To be useful, financial information must not only represent relevant phenomena, but 
it must also faithfully represent the phenomena that it purports to represent. To be a perfectly faithful representation, a depiction would have three characteristics. It would be complete [emphasis added], neutral and free from error' (IASB, Conceptual Framework 2010, QC 12: $18)$.

For financial statements to adhere to these characteristics, each IFRS includes a list of items that companies should disclose. In this way, notes to the financial statements, including those on accounting policies, in which companies provide disclosures in response to these requirements, comprise an integral part of a complete set of financial statements (IAS 1, paragraph 8). The rationale for this reporting approach is that this kind of disclosures assist users of the financial statements to understand a company's underlying economics (i.e., assets, liabilities and equity) and how their values are measured and change from year to year. This is in line with disclosure theories in that, the higher the levels of such disclosures, the higher the amount of both proprietary and non-proprietary information provided to financial statements users (Dye, 1986). This is because accounting policies are chosen by management and, as a result, companies reveal information through their choice of accounting techniques (Dye, 1985). Subsequently, the users of financial statements take into account the policies a company elects as well as the outcomes of these policies. This process allows users of financial statements to make inferences about a company's private information and subsequently make investment decisions.

Additionally, the presence of such a structured framework for mandatory disclosures, would allow experienced users of the financial statements, like analysts, to analyse/interpret the disclosures provided or identify the absence of such disclosures. Again in line with disclosure theories, omission or provision of disclosures mandated by regulations (i.e., accounting standards in this case) may affect investor perceptions about a company's prospects, i.e., they may cause real and/or financial externalities (Dye, 1990). A real externality is created 
when a company's disclosure relates to its own cash flows that may change other companies' cash flows (Dye, 1990). An example is the detailed disclosure of a company's contingent liabilities. A financial externality is created when the disclosures of a company in one industry affect investors' perceptions about the profitability of other companies in the same industry and consequently the latter's market values (Dye (1990) with reference to Foster (1981)).

Thus, it is expected that differential levels of compliance with IFRS mandatory disclosures should be correlated with market values (i.e., being value relevant) and influence analysts' forecasts. Indeed, there is some but scarce evidence in the prior literature which would support this assertion (see more discussion below). In this study, we focus on the disclosures mandated by IAS 36 and IAS 38 for which evidence in this regard is absent.

\subsection{Hypotheses development}

IAS 38 governs the recognition criteria and measurement models as well as relevant disclosures on intangible assets. IAS 38 (paragraph 8) defines an intangible asset as 'an identifiable nonmonetary asset without physical substance'. Even if an item satisfies the definition and recognition criteria of an intangible asset, it should be shown on the statement of financial position of a firm only if a) it is probable that future economic benefits will flow to the enterprise and b) the item has a cost that can be measured with reliability (Tsalavoutas et al., 2014: 25). Goodwill falls out of this definition given that it is a non-identifiable asset, without physical substance. Hence, it is not considered by IAS 38. Goodwill is an asset recognised in a business combination representing future economic benefits arising from expected synergies not individually identified and separately recognised (Mazzi et al., 2017).

Given the nature of such assets and the lack of active markets for them, the estimated value of future economic benefits and the probability that these benefits will flow in the company can be debatable. Nevertheless, prior literature indicates that a large proportion of companies' 
non-current assets consist of goodwill and intangible assets. For example, using a sample of 27,172 European firm-year observations for the period between 2006 and 2015, André et al., (2016) report a mean (median) level of goodwill to total assets of $16.7 \%(11.8 \%) .{ }^{3}$ A study from EFRAG (2016) which examines only the constituents of the S\&P Europe 350, for the same period, finds a similar ratio of $17 \%$ when excluding the financial sector $(3.5 \%$ when included). André et al., (2016) also report a goodwill to equity ratio with a mean (median) of 47.4\% (30.0\%). Mazzi et al., (2017), who like the EFRAG (2016) study focus on the constituents of the S\&P Europe 350 but for the period between 2008 and 2011, find similar levels of goodwill to net book value. In addition, using a sample of very large companies from 23 countries across the world, Tsalavoutas et al., (2014: 26) find that total intangibles (other than goodwill) to total assets range from $1.6 \%$ (in China) to $13.5 \%$ (in the UK), while the value is between $5 \%$ and $10 \%$ for the majority of the remaining countries. ${ }^{4}$

Considering the magnitudes of these values and the fact that companies have investments in other assets as well, the reliability of the amounts of goodwill, intangible assets (and other assets) themselves and/or the anticipation and estimation of a potential impairment, would be of critical importance to users of the financial statements. This is why IAS 36 contains disclosure requirements that 'are designed to improve the reliability of the impairment test' (IAS 36, Basis for conclusions, paragraph 198), which is primarily based on managerial assumptions and proprietary information (Mazzi et al., 2017).

As explained by Mazzi et al., (2016: 354), with reference to evidence from CFOs of Italian listed firms, 'IAS 36 is perceived as a complex, detailed and atypical accounting standard among the IFRS, allowing for subjectivity in its application, being adaptable to managerial needs and unable to limit creative accounting'. This is because IAS 36 sets the procedures that

\footnotetext{
${ }^{3}$ André et al., (2016) report similar values for companies in the US for the same period.

${ }^{4}$ Further, McInnis and Monsen (2017), whose dataset contains 4,166 firm-years containing at least one acquisition in the US for the period between 2003 to 2014, report that intangibles (other than goodwill) make up on average $35.0 \%$ of the purchase price, resulting identifiable intangible assets of $\$ 730$ billion.
} 
a firm should apply to ensure that its assets are carried at no more than their recoverable amount. If an asset is carried at a value higher than its recoverable amount, it has to be impaired and an impairment loss immediately recognised in profit or loss, unless the asset is carried at revalued amount where an adjustment in other comprehensive income may have to take place first (IAS 36, par. 59-60). Given that the impairment testing process relies critically on the estimation of an asset's recoverable amount, the largest part of the standard is devoted to the measurement of the recoverable amount. Extensive discussion is provided around the identification of Cash Generating Units (CGUs), the allocation of goodwill to CGUs, the recognition of an impairment loss and its reversal. More specifically, to assist users' understanding and to alleviate the concerns around the inherent flexibility in the impairment testing process, IAS 36 requires preparers to disclose information mostly related to the assumptions made in estimating recoverable amount, to any reasonably possible changes in these estimates, and to the events and circumstances that led to the recognition or reversal of an impairment loss.

The two standards we focus on require disclosures regarding the assumptions and the methods used to determine accounting items recognised in the financial statements. Some examples of mandatory disclosures within these standards which could provide value relevant information to investors and thus have valuation implications include the following: a) the amount of impairment losses and reversals of such losses recognised during the period (IAS $36)$; b) the events and circumstances that led to the recognition of such impairment losses and reversals of such losses (IAS 36); c) if recoverable amount is measured at fair value less costs to sell: the basis used to determine fair value less costs to sell (IAS 36); d) if recoverable amount is measured at value in use: the discount rate(s) used in the current estimate and previous estimate (if any) of value in use (IAS 36); e) the amortisation methods used for intangible assets with finite useful lives (IAS 38); f) a reconciliation of the carrying amount of intangible assets 
(including goodwill) at the beginning and end of the period (IAS 38); and h) the aggregate amount of research and development expenditure recognised as an expense during the period (IAS 38).

The disclosure of such information enhances faithful representation and overall transparency (Pownall and Schipper, 1999). It provides the users of financial statements with information regarding how the company perceives its prospects (Hope, 2003a). These arguments are particularly relevant to the present study since these standards force companies to disclose information irrespective of these providing good or bad news to the users of financial statements (cf. Verrecchia, 2001). Our research instrument captures whether this information is disclosed and our tests explore whether these disclosures are informative for forecasting earnings and for valuation purposes. Accordingly, we test the following hypotheses, in the alternative form:

Hypothesis 1 - (H1): IFRS mandatory disclosure levels (for each individual standard as well as in aggregate) are value relevant.

Hypothesis 2 - (H2): IFRS mandatory disclosure levels (for each individual standard as well as in aggregate) increase analysts' forecast accuracy.

Hypothesis 3 - (H3): $\quad$ IFRS mandatory disclosure levels (for each individual standard as well as in aggregate) reduce analysts' forecast dispersion.

As far as $\mathrm{H} 1$ is concerned, we do not predict the sign of the relationship between market value and mandatory disclosures. Prior literature suggests positive valuation implications of increased levels of (voluntary) disclosure. However, the implications of mandatory disclosures are 'theoretically far from clear and heavily debated' (Bushee and Leuz 2005: 234). Therefore, as discussed above, higher compliance leads to higher levels of disclosure of both proprietary and non-proprietary information and/or both good and bad news (cf. Leuz and Wysocki, 2008; Verrecchia, 2001). Accordingly, higher compliance may have a positive impact on one company's market value but a negative impact on another's. 
Furthermore, complying with detailed IFRS mandatory disclosures implies high direct costs for companies. Non-compliance costs include monetary fines, market pressure and the threat of de-listing. Depending on the institutional environment, if the costs of compliance with mandatory disclosures are high and the non-compliance costs negligible, non-compliance companies might be better off not disclosing all the information required (cf. Hassan et al., 2009). In fact, investors may even be suspicious of a company with high compliance within a regime where enforcement is low. In such an environment, incurring high direct costs for achieving high compliance may place a company 'at a competitive disadvantage relative to its competitors who failed to publish such mandatory details' (Hassan et al., 2009: 85).

An illustrative example of the above arguments are the mixed findings of Hassan et al. (2009), Tsalavoutas and Dionysiou (2014) and Abdullah et al. (2015). Hassan et al. (2009) examine the value relevance of mandatory disclosure levels for a sample of 80 Egyptian firms, over the period 1995 to 2002 . The second study examines the value relevance of compliance with IFRS mandatory disclosure requirements for a sample of 139 Greek firms in 2005. Hassan et al. (2009) report a negative relationship and Tsalavoutas and Dionysiou (2014) find a positive relationship between market values and mandatory disclosure levels. Nevertheless, Abdullah et al. (2015) examine the value relevance of mandatory disclosure levels for a sample of 225 Malaysian firms for 2008. They find that mandatory disclosure levels are not value relevant.

As for $\mathrm{H} 2$ and $\mathrm{H} 3$, there is very little research that has examined the impact of mandated disclosures on analysts' forecast characteristics. Hope (2003b) finds that the level of accounting policy disclosures is significant and negatively related to consensus forecast errors and dispersion, and that accounting policy disclosures are incrementally useful to analysts over and above all other annual report disclosures. This is consistent with the view that such disclosures reduce uncertainty about forecasted earnings. In a related study, Hope (2003a) reports the 
important role of enforcement, arguing that enforcement encourages firms to follow prescribed rules, which in turn reduces investors' uncertainty and leads to more accurate analysts' forecasts. He provides evidence that both disclosure and strong enforcement are associated with improved consensus forecast accuracy.

A number of papers examine the impact of differing accounting standards or the introduction of IFRS on analysts' forecast characteristics (Bae et al. 2008; Byard et al. 2011; Glaum et al. 2013a; Horton et al. 2013; Tan et al. 2011). They argue and find that better quality standards reduce forecast errors and dispersion. Looking more specifically at disclosure quality, Hodgdon et al. (2008) investigate the relationship between analysts' earnings forecast errors and firm compliance with the disclosure requirements of IFRS around 1999-2000. They document that forecast error is negatively related to IFRS compliance suggest that compliance with the disclosure requirements of IFRS reduces information asymmetry and enhances the ability of financial analysts to provide more accurate forecasts. Their findings also support the viewpoint that the extent of compliance with accounting standards is as important as the standards themselves. Our paper differs from theirs in that they examine a period when IFRS were voluntary and much less developed, whereas we examine a period when IFRS are mandatory and disclosure requirements are more developed.

\section{Data and research design}

\subsection{Measuring compliance with IFRS mandatory disclosure requirements}

We follow Glaum et al. (2013b) and Tsalavoutas (2011) in the method for measuring compliance. A disclosure index containing all the items mandated by IAS 36 and IAS 38 is 
used as a scoring sheet for each company. We base our scoring sheet on the one developed by Tsalavoutas (2011), which has already been tested for its validity. We updated this scoring list in line with the requirements introduced and the changes made to the two standards that were applicable for the financial periods beginning after 1 July 2009. The final disclosure checklist includes 58 mandatory items: 39 relate to IAS 36 and 19 items relate to IAS 38.

Subsequently, we compute a disclosure score with regard to the disclosures mandated by each standard separately (i.e., IAS36_CS and IAS38_CS) via an unweighted disclosure index method. This approach assumes that each mandated item is of equal importance. So, if a required item was disclosed, it was scored as 1 and if not, it was scored as 0 . Some items might not be applicable to every company, and were therefore scored as 'not applicable'. ${ }^{5}$ Following this, the compliance with each standard's mandatory disclosures is calculated as the ratio of the total items mandated by this particular standard and disclosed by each firm to the maximum items from that standard which are applicable to that company. This is expressed as follows:

$$
C_{j}=\frac{T=\sum_{i=1}^{n} d_{i}}{M=\sum_{i=1}^{m} d_{i}}
$$

Where $C_{j}$ is the total compliance score for each company and is restricted between 0 and 1. $T$ is the total number of items disclosed $\left(d_{i}\right)$ by company $j$ and $M$ is the maximum number of applicable disclosure items for company $j$ that could have been disclosed following a standard's requirements.

In addition to these two separate measures, we compute two average scores. In the first (Aver_1), we assume that each standard is of equal importance, and thus, each standard has equal weight. So, this average score is the total compliance score for each company and is

\footnotetext{
${ }^{5}$ In order to avoid penalising a company for non-compliance with a standard or item which might not be applicable, a thorough reading of the complete annual is needed prior to proceeding with examining compliance (Cooke, 1992). This approach was followed in the present study.
} 
restricted between 0 and 1 . It is obtained by the calculation of the compliance with each standard's mandatory disclosures separately $\left(C_{j}\right)$, adding these compliance scores (i.e., IAS36_CS and IAS38_CS) and dividing the sum by the total number of relevant/applicable standards for each company $j$.

Given the significantly different number of items required by IAS 36 compared to IAS 38 , we consider this aggregate score capturing compliance with these two standards in a more balanced/appropriate way. This is in line with Tsalavoutas et al.'s (2010) suggestion that this method is more appropriate for measuring compliance levels with a number of standards or information categories, when the number of items in each of them varies significantly and if each standard/category are perceived of equal importance.

In the second (Aver_2), each mandated item is of equal importance, irrespective of how many items a standard mandates and in which standard the item is included. Again, this score is the total compliance score for each company and is restricted between 0 and 1 . It is derived by dividing the total number of items disclosed by a company by the maximum number of applicable disclosure items for that company that could have been disclosed following both standards' requirements. (See Tsalavoutas et al. (2010) and Tsalavoutas (2011) for details on these two scoring methods). ${ }^{6}$

\subsection{Sample}

The study period has been decided as follows. Because of a desired convergence on the topic of business combinations between the IASB and FASB, for financial periods starting on or after 1 July 2009, IFRS 3 became effective. The revisions in this standard introduced a number

\footnotetext{
${ }^{6}$ To ensure the reliability of the research instrument, we scored 10 randomly selected companies independently. We then compared our findings. Given that the final research instrument had been agreed by all investigators, differences in the compliance scores across the investigators were insignificant.
} 
of significant changes in the way business combinations are recorded and how goodwill and other intangible assets are valued when a business combination is recognised. Additionally, because of this revised standard, changes were introduced in IAS 36. As a result, we chose to examine compliance with mandatory disclosures in the areas that are relevant to these two standards (i.e., intangible assets and their impairment) in the first year of their implementation.

Our sample represents the 'blue chip' companies (excluding the financial institutions) in Europe. ${ }^{7}$ We first collect data for the non-financial constituents of the S\&P Europe 350 Index, which includes the largest and more liquid EU companies. In addition to these companies, European firms included in large-cap country-specific indices are added to the potential sample in order to increase sample size at the country level. Firms cross-listed in more than one country of investigation are included only for the country of primary listing. Firms with dual shares are excluded. ${ }^{8}$ After identifying the financial year end for each firm, the company annual report is collected from the company's webpage or Thomson One Banker database. Firms following US GAAP and Canadian GAAP are excluded. Firms for which financial or other necessary data are not available are also excluded.

As the research investigates levels of compliance with two standards, firms for which none of the two standards apply are removed from the sample. The disclosures required by IAS 36 are applicable even if a firm does not recognise any impairment loss, simply because it has to test goodwill and other intangible assets with indefinite useful lives annually for impairment. If an impairment and/or a reversal of an impairment takes place and is material, further disclosures are triggered. A 5\% threshold of impairment over profit before tax is applied to

\footnotetext{
${ }^{7}$ We exclude financial companies because of the differences in the nature of their operations and because they are subject to different regulations. This is common in the relevant literature on compliance with mandatory disclosures (e.g., Mazzi et al., 2017; Abdullah et al., 2015) as well as the literature examining analysts' forecasts (e.g., Bozzolan et al., 2009; Glaum et al., 2013a).

${ }^{8}$ This results in the exclusion of six potential observations. However, although a firm may be listed in more than one stock-markets, its financial statements are the same. Hence, we cannot include the same compliance scores and financial statements related items twice in the sample.
} 
determine whether an impairment or a reversal of an impairment was regarded as material and, therefore, should necessitate more relevant disclosures. As a result, to render the standard inapplicable, a firm should not have any goodwill or intangible assets with indefinite useful life and should not have recognised a material impairment or reversal of impairment for its remaining assets. As far as disclosure mandated by IAS 38 is concerned, if a company elects to report separately the net book value of a class of intangible assets in its financial statements, it is assumed that the company considers this item to be material and, as a result, the corresponding mandated disclosure should be disclosed.

Following the application of these criteria, 373 companies from 16 EU countries were left in the sample for the reporting year 2010/11. Table 1 shows the number of firms across country and industry. Most sample firms are listed in the UK (83) and France (42) and are part of the Industrials (99), Basic Materials (42), Consumer Services (51) and Consumer Goods (57) International Classification Benchmark (ICB) industry sectors.

\section{TABLE 1 ABOUT HERE}

\subsection{The models employed}

To test H1, we follow Kohlbeck and Mayhew (2010), Sinkin et al. (2008) and Clarkson et al. (2013), among others, and use Ohlson's (1995) model as a framework. The model can be expressed as follows:

$$
P_{j}=\alpha_{0}+\alpha_{1} \mathrm{~B}_{j}+\alpha_{2} \mathrm{X}_{j}+\alpha_{3} v_{j}+\varepsilon_{j}
$$

where $P_{j}$ stands for the value of a company, $B_{j}$ is the book value of shareholders' equity, $X_{j}$ net profit and $v$ is 'other information' available to the market participants but not yet captured by accounting (i.e. events that have not yet affected B and X) (Myers, 1999), and $\varepsilon_{j}$ is the mean zero disturbance term.

This valuation framework combines accounting and non-accounting data. Ohlson (2001) explains that excluding $v$ from the equation makes the model 'patently simplistic'. Assuming 
$v$ is zero implies that what matters in the setting of market values is only the publicly available information of the book value of shareholders' equity and net income. Expectations or information about future prospects and future income which essentially are not recognised in the financial statements are 'heroically' assumed to be of no relevance. This may lead to potentially inaccurate conclusions regarding the coefficients of the variables included in the model.

Following along these lines, the compliance score of each company $(C S)$ is included in Equation 2, as a third independent variable (i.e., as a proxy for 'other information'). In addition, considering that our sample firms are listed in countries of significantly different socioeconomic contexts, we include additional country-specific controls. The extent to which financial statements' quality is high or low and the extent to which financial statements are trusted by investors as tools for investment decisions (i.e., the extent to they are value relevant and also influence analysts' forecasts) may depend on the socio-economic context of each country in our sample. ${ }^{9}$ These additions lead to the following equation:

$$
\begin{aligned}
& M V_{j}=a_{0}+b_{1} B V E_{j}+b_{2} N I_{j}+b_{3} C S_{j}+b_{4} M k t_{-} \text {Dev }_{j}+b_{5} \text { Enforce }_{j}+b_{6} A W C A_{j}+b_{7} \operatorname{Re}_{\text {adability }_{j}}+ \\
& +b_{m}\left(\sum \text { DLegalOrigin }\right)+\varepsilon_{j}
\end{aligned}
$$

where $M V_{j t}$ is the market value of a company $j$ four months after the publication of the financial statements relating to the financial period (WC08001). (This ensures that the accounting information is in the public domain and has been 'absorbed' by investors (cf. Tsalavoutas et $a l ., 2012) ; B V E_{j}$ is the book value of net assets at the end of the financial period (WC03501);

\footnotetext{
${ }^{9}$ For example, higher earnings' quality could result in higher value relevance of earnings. Additionally, the more readable a company's financial statements, the easier for financial statement users to comprehend and analyse the information in them. This would lead to higher value relevance of accounting information. Further, the higher the enforcement mechanisms of accounting and security regulations, the higher the value relevance of accounting information would be. Finally, the more developed a market is, the more sophisticated investors would follow listed firms and analyse their financial statements. This would lead to higher value relevance of accounting information. Following along these lines, these characteristics would result in lower analysts' forecasts' errors and dispersion.
} 
$N I_{j}$ is the net profit after tax for the financial period (WC01751); $C S_{j}$ is the mandatory disclosure compliance score; $M k t_{-} D e v_{j}$ is the market capitalisation of listed companies as a percentage of GDP for each country (World Bank); Enforce $_{j}$ is an index combining the level of activity of independent enforcement bodies and important features of the audit environment likely to affect the quality of enforcement of financial reporting requirements by auditors in a country where the higher the index the stronger the enforcement environment (see Preiato et al. 2013); $A W C A_{j}$ is the absolute value of abnormal working capital accruals scaled by total assets (see DeFond and Park 2001); ${ }^{10}$ Readability is the logarithmic transformation of annual report page count; the vector DLegalOrigin is a set of dummy variables capturing legal systems of French, Scandinavian and German origin with English being the benchmark group (see Djankov et al. 2008); and $\varepsilon_{j}$ is the mean zero disturbance term.

We test $\mathrm{H} 2$ and $\mathrm{H} 3$ by employing the following regression models:

$$
\begin{aligned}
& \text { Disper }_{j}=a_{0}+b_{1} C_{j}+b_{2} \text { Mkt_Dev }{ }_{j}+b_{3} \text { Enforce }_{j}+b_{4} A W C A_{j}+b_{5} \text { Re } \text { adability }_{j}+b_{6} \text { SIZE }_{j}+ \\
& b_{7}{\text { Im } \text { pair }_{j}+b_{8} \text { Int }_{j}+b_{9} \text { AnFol }}_{j}+b_{10} \text { Hor }_{j}+b_{11} \text { Loss }_{j}+b_{12} N I_{-} C_{j}+b_{13} U_{-} S_{-} \text {List }_{j}+b_{14} \text { Ind }_{j}+ \\
& b_{m}\left(\sum \text { DLegalOrigin }\right)+\varepsilon_{j}
\end{aligned}
$$

$$
\begin{aligned}
& \text { Accur }_{j}=a_{0}+b_{1} \text { CS }_{j}+b_{2} \text { Mkt }_{-} \text {Dev }_{j}+b_{3} \text { Enforce }_{j}+b_{4} \text { AWCA }_{j}+b_{5} \text { Re } \text { adability }_{j}+b_{6} \text { SIZE }_{j}+ \\
& b_{7} \operatorname{Im}_{\text {pair }_{j}}+b_{8} \text { Int }_{j}+b_{9} \text { AnFol }_{j}+b_{10} \text { Hor }_{j}+b_{11} \text { Loss }_{j}+b_{12} N I_{-} C_{j}+b_{13} \text { US }_{-} \text {List }_{j}+b_{14} \text { Ind }_{j}+ \\
& b_{m}\left(\sum \text { DLegalOrigin }\right)+\varepsilon_{j}
\end{aligned}
$$

where Disper $_{j}$ is the standard deviation of analysts' forecasts (I/B/E/S) (last I/B/E/S forecast prior to the EPS announcement), scaled by share price; $A c c u r_{j}$ is the absolute value of the difference between mean $\mathrm{I} / \mathrm{B} / \mathrm{E} / \mathrm{S}$ forecast (last $\mathrm{I} / \mathrm{B} / \mathrm{E} / \mathrm{S}$ forecast prior to the $\mathrm{EPS}$ announcement) and actual EPS, scaled by stock price [we multiply this variable by -1 so as to

\footnotetext{
${ }^{10} \mathrm{AWCA}=(\mathrm{WCt}-\mathrm{WCt}-1 * \mathrm{St} / \mathrm{St}-1) / \mathrm{TAt} . \mathrm{WC}$ stands for working capital accruals, computed as current assets (WC02201) - cash \& equivalents (WC02001) - current liabilities (WC03101) + short term debt (WC03051).
} 
be interpreted as accuracy; the higher the better]; $S I Z E_{j t}$ is natural logarithm of the market value of a company $j$ four months after the publication of the financial statements (WC08001); Impair $_{j}$ is an indicator variable that takes 1 if an impairment is reported and 0 otherwise (hand collected); Int $t_{j}$ is the ratio between total intangible assets, including goodwill, and total assets (hand collected); $A n F o l_{j}$ is the number of analysts contributing to the forecast as reported by $\mathrm{I} / \mathrm{B} / \mathrm{E} / \mathrm{S} ; H_{0} r_{j}$ is measured as the number of months from the forecast date until the company releases its actual earnings (I/B/E/S); $\operatorname{Loss}_{j}$ is an indicator variable for loss making companies; $N I \_C h_{j}$ is the absolute value of the change in earnings between current earnings and that of the previous year, scaled by last year's earnings; US_List $t_{j}$ is a binary variable that takes a value of one when the firm is listed in the US and zero otherwise (identified via DataStream); Ind $d_{j}$ takes a value of one when a firm is categorised into 'manufacturing' on the basis of their industry participation, according to ICB, and zero otherwise. ${ }^{11}$ All remaining variables are the same as in Equation 4.

All monetary values are converted into euros. If the firm's reporting currency is not the euro, the corresponding historic (daily) bilateral exchange rate, as at the financial year end day, stated on the European Central Bank website is used to convert the collected figures in euros (or as at four months later when calculating the firm market value four months after the yearend).

In all our tests, we employ the 'Heteroskedasticity-consistent covariance matrix estimator 3 (HC3)', to address concerns related to heteroskedasticity. This alternative method tends to produce better results than White's (1980) basic method, as it produces confidence intervals which tend to be even more conservative (MacKinnon and White, 1985). As heteroskedasticity

\footnotetext{
${ }^{11}$ Ind equals one when a firm operates in one of the following industry sectors: basic materials, consumer goods, industrials, oil and gas or technology. Consequently it takes a value of zero when the company is in the consumer services, healthcare, telecommunications or utilities industries. Arguably, this dummy may not capture the diversity of industries in the sample. Hence, we repeat all our analyses by substituting the one dummy variable we now have, with industry fixed effects based on the ICB Level 2 as this indicated in Table 1. These results confirm the findings of our main analyses.
} 
can also arise from the presence of outliers, we define and exclude outliers when the standardised residuals lie outside the range of $+/-2$ standard deviations.

The scale bias is another common problem when one implements the Ohlson (1995) model since it may introduce heteroskedasticity. To address this issue, in Equation 4, we scale $M V$, $B V E$ and NI by total assets. ${ }^{12}$ Finally, multicollinearity was checked with a variance inflation factor $(\mathrm{VIF})>10$ as a threshold and maximum VIF is reported for every regression presented in our results, suggesting no multicollinearity issues.

\section{Empirical findings and discussion}

\subsection{Compliance levels}

Table 2 reports the frequency and distribution of the compliance scores across our sample firms. Mean (median) degree of average compliance (Aver_l) is relatively high: $83.9 \%$ $(85.7 \%)$. However, consistent with prior studies, high variation is observed among firms' mandatory disclosure levels (e.g., Al-Shammari et al. 2008, Al-Akra et al. 2010, Tsalavoutas 2011, Glaum et al. 2013b). The standard deviation is $13.4 \%$ while the minimum compliance level is $25 \%$. Nevertheless, there are many fully compliant firms. In fact, $37 \%$ of the sample firms is disclosing between $90 \%$ and $100 \%$ of the required disclosures but some $32 \%$ of the sample firms only complies between $25 \%$ and $79 \% .{ }^{13}$ This important variability of compliance scores indicates that a differential quantity of information reached the users of financial statements.

The levels of compliance with individual standards confirm the variability of disclosures provided. Mean (median) compliance with IAS 36 is $81.9 \%(85.7 \%)$ and compliance for this standard exhibits a very high standard deviation (18.9\%). A noted finding is that 61 firms (i.e.,

\footnotetext{
${ }^{12}$ Repeating the analysis by using the number of shares outstanding as an alternative scaling factor does not lead to qualitatively different conclusions.

${ }^{13}$ The findings regarding Aver_2 are qualitatively similar and are not discussed for brevity.
} 
$16.3 \%$ of our sample) exhibit compliance levels between $0 \%$ and $69 \%$. Mean and median compliance with the requirements of IAS 38 is higher to that of IAS 36 (i.e., $85.9 \%$ and 90\%). Although still high, the standard deviation of compliance for this standard is lower than IAS 36 (i.e., 15.5\%). The number of companies exhibiting compliance levels lower than $69 \%$ is identical to IAS 36 (i.e., 61), but no firm exhibits compliance levels lower than 33.3\%. Further, 295 (79.1\% of our sample firms) exhibit compliance between $80 \%$ and $100 \%$.

\section{TABLE 2 - ABOUT HERE}

Table 3 provides information regarding specific items mandated by IAS 36 and IAS 38 which are applicable to equal or more than $20 \%$ of our sample firms (i.e., 73 companies) and for which high non-compliance (i.e., less than $90 \%$ compliance) is observed. The compliance levels with these items are indicative of the variation of important firm-specific information that reaches users of financial statements. In fact, these descriptive statistics reveal the discretion companies apply with regard to provision of proprietary and non-proprietary information around intangible assets and impairment tests which could reveal good and bad news. From the standard setter's point of view, this list of items reveals areas within individual IFRS which may need to be addressed, either at the standard level or within the IASB's Disclosure Initiative project, by providing guidance on how these requirements should be interpreted and applied by companies. We highlight noticeable observations.

Regarding the disclosures mandated by IAS 36, our analysis reveals that many companies do not disclose the actual impairment loss or a reversal of impairment loss across reportable segments. Furthermore, many firms do not disclose the main events and circumstances that led to the recognition of impairment losses or reversal of impairment losses. Moreover, for the majority of our sample firms which use the value in use impairment testing method for goodwill or intangible assets with indefinite useful lives, a large proportion of them remains silent regarding aspects of the impairment testing process (e.g., description of assumptions used, the 
approach used for determining these assumptions, justifications about the period of cash flows used and/or the growth rate used to extrapolate cash flows beyond the period covered by management budgets).

Many of these items can be described as proprietary because there is evidence from preparers themselves that this information will probably not be disclosed on a voluntary basis. This is because it can cause significant commercial harm to an entity and may be used to initiate litigation against it in the event that these assumptions prove less than accurate (see the evidence from preparers as provided in ASBJ et al., 2014). However, this information could be critical for investors, analysts and lenders in their decision-making process (see relevant discussion in FRC, 2014; KPMG, 2014). In fact, being able to predict the outcome of the impairment testing is an important input to users' assessment of the amount, timing and uncertainty of (the prospect for) future net cash inflows (see the evidence from preparers as provided in ASBJ et al., 2014).

Not disclosing this information appears to confirm the concerns expressed in the literature about the quality of goodwill impairment tests (Hoogendoorn 2006, Carlin and Finch 2009, 2010) which can lead to decisions that essentially serve earnings management, reducing the information value to investors (Ramanna and Watts, 2012). Finally, a large number of firms does not reveal the carrying amount of goodwill and/or intangible assets with indefinite useful lives allocated to one or more of its cash-generating units (group of units). Lack of this information would further hinder investors' ability to evaluate the risks and returns associated with key components of a firm.

Looking into the disclosures mandated by IAS 38, similarly, a large number of our sample firms apply discretion around information that would allow readers of the financial statements to evaluate how the company's profit has been derived and how the company perceives its future prospects. More specifically, information about whether the useful lives of intangible 
assets are indefinite or finite and, if finite, the useful lives or the amortisation rates used; the amortisation methods used for intangible assets with finite useful lives; and the line item(s) of the statement of comprehensive income in which any amortisation of intangible assets is included is not disclosed by a large number of firms. Additionally, many of the firms which have intangibles asset(s) with an indefinite useful life remain silent regarding the reasons justifying this designation and the factor(s) that played a significant role in determining that the asset has an indefinite useful life.

TABLE 3 - ABOUT HERE

\subsection{Univariate analyses}

Table 4 reports descriptive statistics for the dependent and independent variables used in the multivariate analyses. Mean (median) market value of equity to total assets $(M V)$ is $1.07(0.81)$. Mean (median) Disper is 0.07 (0.01) and mean (median) Accur is -0.08 (-0.01). Mean for Impair is $69 \%$, indicating that $69 \%$ of our sample firms recognise an impairment. Additionally, mean (median) of Int is $29 \%(21 \%)$, indicating that a material value of total assets relates to intangible assets. The prior two findings suggest that a large number of our sample firms would be required to provide more disclosures under IAS 36 and IAS 38 because of recognising impairments and large values of intangibles.

Firms are followed by about 3 analysts $(A n F o l)$. The dummy variable $U S \_$List shows that nearly one quarter of our sample firms are listed both in a European market and in the US. Variation with regard to market development and enforcement mechanisms among the countries investigated is also evident.

\section{TABLE 4-ABOUT HERE}

Pearson's correlation coefficients between all variables are presented in Table 5. As one would expect, the average disclosure scores (Aver_l \& Aver_2) correlate highly positively (coefficient of $0.956, p<0.01$ ). Statistically significant is also the correlation between the 
disclosure scores of each separate standard (IAS36_CS and IAS38_CS). Consistent with our hypotheses, preliminary evidence shows that there is a positive and statistically significant correlation between $M V$ and mandatory disclosure Aver_1, Aver_2, IAS36_CS and IAS38_CS: $0.146(p<0.01), 0.136(p<0.01), 0.103(p<0.01)$, and $0.125(p<0.05)$, respectively. Additionally, there is a positive and statistically significant correlation between Disper and mandatory disclosure Aver_1, Aver_2, IAS36_CS and IAS38_CS: $0.192(p<0.01), 0.197(p<$ $0.01), 0.196(p<0.01)$ and $0.092(p<0.10)$ respectively. We are at odds to explain the negative and statistically significant correlation between Accur and mandatory disclosure, but these remain univariate tests.

From the correlations reported among the remaining variables we highlight the following. Both enforcement (Enforce) and market development (Mkt_Dev) document positive and highly significant correlations $(p<0.01)$ with both the average disclosure score (Aver_l and Aver_2) and the score regarding IAS 36 related disclosures (IAS36_CS). This suggests that the stronger the enforcement in a country and the more developed a market is the higher the levels of mandatory disclosures provided to the market participants are.

TABLE 5 - ABOUT HERE

\subsection{Multivariate analyses}

Table 6 reports the findings of the multivariate analyses regarding our three hypotheses. Starting with $\mathrm{H} 1$, the average compliance scores (Aver_l and Aver_2) are positively related to market values (coefficients of 0.452 and $0.520, p<0.05$ respectively). When looking at the tests by disaggregating the combined compliance scores i.e., by testing the potential value relevance of compliance with the disclosure requirements of each standard separately, we find that only the disclosure levels regarding IAS 36 are value relevant (IAS36_CS has a coefficient of $0.328, p<0.01$ ). These findings allow us to infer strong support for our first hypothesis, 
while they suggest that the variation in the disclosures associated with IAS 36 matter most to investors.

Turning into the tests regarding $\mathrm{H} 2$, the average compliance scores (Aver_l and Aver_2) are negatively related to analysts' forecast dispersion (coefficients of -0.066 and 0.062 , both significant at the 5\%). When looking at the tests regarding the disclosure requirements of each standard separately, we also find that only the disclosure levels regarding IAS 36 reduce analysts' forecast dispersion (IAS36_CS has a coefficient of $-0.044, p<0.05)$. These findings also allow us to infer strong support for second hypothesis, although they similarly suggest that the variation in the disclosures associated with IAS 38 does not affect analysts' forecast dispersion.

Finally, when looking at the results regarding our third hypothesis, we note the following. The average compliance scores (Aver_l and Aver_2) are not related to analysts' forecast accuracy. Nevertheless, we also find that only the compliance scores regarding IAS 36 improve analysts' forecast accuracy (IAS36_CS has a coefficient of 0.055, significant at the 5\% level). Thus, these findings allow us to also infer some support for our third hypothesis. They suggest that only the variation in the disclosures associated with IAS 36 results in analysts making fewer errors while forecasting company's earnings.

The consistent evidence about the implications arising from the disclosure levels associated with what IAS 36 mandates is not surprising, given the great disparity of information disclosed as indicated in Table 3. The fact that a large number of companies recognise an impairment and have very large amounts of intangible assets (including goodwill) recognised on their balance sheets, would make the disclosure of associated information even more relevant to investors.

TABLE 6 - ABOUT HERE 
Overall, these results indicate that levels of mandatory disclosure requirements do convey information to investors which assists in predicting future earnings. Furthermore, these findings imply that companies with higher compliance exhibit higher market values. Thus, companies exercising positive discretion on disclosing information which provides proprietary information and reveals managers' judgement and expectations, benefit from an increased market value. It appears that high compliance companies are perceived as 'good' and 'responsible', representing 'good practice' and consequently are 'rewarded' by investors (cf. Goncharov et al., 2006).

\section{Conclusions}

We consider relevance and faithful representation of IFRS mandatory disclosures as a key feature of companies' financial statements and we score compliance with the mandatory disclosure requirements of IAS 36 and IAS 38 for a sample of 373 listed companies from European countries in 2010/11. This is the first year of the revised versions of these standards as a result of the revised IFRS 3. Considering that complying with the standards' mandatory disclosure requirements implies disclosure of information, we subsequently explore the value relevance of these compliance/disclosure levels and their effects on analysts' forecast accuracy and dispersion. This analysis is also motivated by surveys from professional bodies and/or standard setters who report the views of analysts on the subject (e.g., EY 2010; KPMG 2014; FRC, 2014; ASBJ et al. 2014). All of them identify disclosures in IAS 36 and IAS 38 as key for informing analysts' investment decisions.

We document evidence that companies exercising positive discretion on disclosing information which provides proprietary information and reveals managers' judgement and expectations, benefit from an increased market value. Additionally, for companies exercising such discretion, analysts make less dispersed forecasts and these are more accurate. This 
evidence supports the argument that mandatory disclosures provide insights into key accounting matters and result in more transparent financial statements (c.f., Pownall and Schipper 1999) which, in turn, reduces economic uncertainty about companies (Hope 2003, Anctil et al. 2004).

Our study contributes to knowledge in the following ways. First, we provide useful insights to standard setters and respond to Buijink's (2006) and Teixeira's (2014) calls for academic research that could assist in the development of more evidence-informed accounting standardsetting. Reflecting on recent concerns by standard setters and regulators (e.g., ANC 2011, EFRAG et al. 2012, FRC 2012, ESMA 2013, Hoogervorst 2013, IASB, 2013) about the usefulness of mandatory disclosures, this study informs in this debate by revealing issues arising in practice and relate to the application of existing IFRS for which specific guidance/principles of disclosures is absent. Our findings suggest that further guidance and existence of communication principles would be a positive step forward. This will contribute to the completeness of the individual standards and could result in the improvement of individual standards and the overall framework for financial reporting. Second, this study responds to the relevant calls for research on empirical evidence about the economic consequences of mandatory disclosures (see Leuz and Wysocki, 2016; Hassan et al., 2009; Bushee and Leuz, 2005; Kang and Pang, 2005).

The findings are subject to the limitation that applies to all studies measuring compliance with mandatory disclosure requirements: although the necessary procedures and specific criteria were followed, measuring compliance with mandatory disclosures always entails a degree of subjectivity. Additionally, our research focuses on a single year. Considering the significant amount of time required for manually scoring each company in the sample, we opted for capturing diversity across different countries for the first year following the implementation of the revised standards. Thus, we examine a large number of observations across many 
countries, instead of covering more years but for a smaller number of countries. Future research could examine compliance with other IFRS' (or other national standards') mandatory disclosures for longer periods and for financial firms which are excluded from this study.

\section{References}

Abdullah, M. Evans, L. Fraser, I. \& Tsalavoutas, I. 2015. IFRS Mandatory disclosures in Malaysia: the influence of family control and the value (ir)relevance of compliance levels, Accounting Forum, 39(4), pp. 239-370.

Al-Akra, M., Eddie, I.A., \& Ali, M.J. 2010. The influence of the introduction of accounting disclosure regulation and mandatory disclosure compliance: Evidence from Jordan. British Accounting Review, 42(3), 170-186.

Al-Shammari, B., Brown, P. and Tarca, A. 2008, An investigation of compliance with international accounting standards by listed companies in the Gulf Co-Operation Council member states, The International Journal of Accounting, Vol. 43, No.4, pp. 425-447. 
Anctil, R.M., Dickhaut, J., Kanodia, C. and Shapiro, B. (2004), 'Information Transparency and Coordination Failure: Theory and Experiment', Journal of Accounting Research, Vol. 42, No. 2, pp. 159-195.

André, P., Filip, A., \& Paugam, L. 2016. Examining the patterns of goodwill impairments in Europe and the US. Accounting in Europe, 13(3), 329-352.

Autorité des Normes Comptables (ANC), 2011. Simplifying accounting obligations for small listed compagnies in Europe. Available from http://www.anc.gouv.fr/sections/nos_publications/nos_publications_fic/small_listed_co mpani/downloadFile/file/Small_listed_companies__MAJ_oct_2011_VDEF.pdf?nocache=1318521111.88 [Accessed 31 March 2014].

Bae, K., Tan, H. and Welker, M. (2008) 'International GAAP differences: The impact on foreign analysts' The Accounting Review, Vol. 83, No. 3, pp. 593-628.

Barth, M.E. and Schipper, K. (2007), 'Financial Reporting Transparency, Journal of Accounting, Auditing and Finance, Vol. 23, No. 2, pp. 173-190.

Bozzolan, S., Trombetta, M., \& Beretta, S. (2009). Forward-looking disclosures, financial verifiability and analysts' forecasts: A study of cross-listed European firms. European Accounting Review, 18(3), 435-473.

Buijink, W. (2006). Evidence-based financial reporting regulation. ABACUS, 42(3-4), 296301.

Bushee, B. and Leuz, C. (2005), 'Economic consequences of SEC Disclosure Regulation: Evidence from the OTCBB', Journal of Accounting and Economics, Vol. 39, No. 2, pp. 233-264.

Byard, D., Li, Y. and Yu, Y. (2011) 'The effect of mandated IFRS adoption on analysts' forecast errors', Journal of Accounting Research, Vol. 49, No. 1, pp. 69-96.

Carlin, T. M. and Finch, N. (2010), 'Evidence on IFRS Goodwill Impairment Testing by Australian and New Zealand Firms', Working paper <http://ssrn.com/abstract=1550425>. (9 February).

Carlin, T.M. and Finch, N., 2009. Discount rates in disarray: Evidence on flawed goodwill impairment testing. Australian Accounting Review, 19 (4), 326-336.

Clarkson, P., Fang, X., Li, Y., Richardson, G., 2013. The relevance of environmental disclosures: Are such disclosures incrementally informative? Journal of Accounting and Public Policy, 32 (5), 410-431.

Company Reporting Ltd (2007), 'Issue of the Month: Impairments', No. 201.

Company Reporting Ltd (2008), 'Issue of the Month: Intangible Assets and Amortisation', No. 214.

Cooke, T., (1992), 'The impact of size, stock market listing and industry type on disclosure in the annual reports of Japanese listed corporations', Accounting and Business Research, Vol. 22, pp. 229-237.

Djankov, S., La Porta, R., Lopez-De-Silanes, F. and Shleifer, A. (2008), 'The Law and Economics of Self-Dealing', Journal of Financial Economics, 88 (3): 430-65.

Dye, R.A. (1985), 'Strategic accounting choice and the effects of alternative financial reporting requirements', Journal of Accounting Research, Vol. 23, No. 2, pp. 544-574.

Dye, R.A. (1986), 'Proprietary and nonproprietary disclosures', Journal of Business, Vol. 59, No.2, pp. 331-336.

Dye, R.A. (1990), 'Mandatory versus voluntary disclosures: the case of financial and real externalities', The Accounting Review, Vol. 65, No. 1, pp. 1-24.

EC (European Commission) (2008), 'Evaluation of the Application of IFRS in the 2006 Financial Statements of EU Companies' <http://ec.europa.eu/internal_market/accounting/docs/studies/2009-report_en.pdf>, accessed 10 March 2014. 
EFRAG (European Financial Reporting Advisory Group) (2012), 'Towards a Disclosure Framework for the Notes', discussion paper, resource document <http://www.efrag.org/files/ProjectDocuments/PAAinE\%20Disclosure\%20Framework/1 21015_Disclosure_Framework_-_FINAL1.pdf >, last accessed 25 September 2013.

Ernst \& Young (2009), Acquisition accounting - what's next for you? <http://www2.eycom.ch/publications/items/2009_acquisition_accounting/2009_Acquisit ion_accounting.pdf $>$, accessed 10 March 2014.

ESMA (2013), European Enforcers Review of Impairment of Goodwill and Other Intangible Assets in the IFRS Financial Statements <http://www.esma.europa.eu/system/ files/201302.pdf $>$, accessed 31 March 2014.

Financial Reporting Council (FRC), 2012. Thinking about disclosures in a broader context. A road map for a disclosure framework. http://www.efrag.org/files/ProjectDocuments/PAAinE\%20Disclosure\%20Framework/12 1015_Disclosure_Framework_-_FINAL1.pdf [Accessed 31 March 2014]

Foster, G. (1981), 'Intra-Industry information transfers associated with earnings releases', Journal of Accounting and Economics, (December), pp. 201-232.

FRRP (Financial Reporting Review Panel) (2006), 'Preliminary Report on Implementation of IFRS', Press Notice $98<$ https:// www.frc.org.uk/FRC-Documents/FRRP/PreliminaryReport-on-Implementation-of-IFRS.aspx>, accessed 10 March 2014.

Glaum, M., Baetge, J., Grothe, A., \& Oberdörster, T. (2013a). Introduction of International Accounting Standards, disclosure quality and accuracy of analysts' earnings forecasts. European Accounting Review, 22(1), 79-116.

Glaum, M., Schmidt, P., Street, D. L. and Vogel, S. (2013b), 'Compliance with IFRS3- and IAS36-required Disclosures Across 17 European Countries: Company- and Country-level Determinants', Accounting and Business Research, 43 (3): 163-204.

Goncharov, I., Werner J.R. and Zimmermann, J. (2006), 'Does Compliance with the German Corporate Governance Code Have an Impact on Stock Valuation? An empirical analysis', Corporate Governance: An International Review, Vol. 14, No 5, pp. 432-445.

Hassan, O., Romilly, P., Giorgioni, G. and Power, D. (2009), 'The value relevance of disclosure: Evidence from the emerging capital market of Egypt', The International Journal of Accounting, Vol. 44, No. 2, pp. 79-102.

Hodgdon, C., Tondkar, R. H., Harless, D. W. and Adhikari, A. (2008), 'Compliance with IFRS disclosure requirements and individual analysts' forecast errors', Journal of International Accounting, Auditing and Taxation, Vol. 17, pp. 1-13.

Hoogendoorn, M., 2006. International accounting regulation and IFRS implementation in Europe and beyond - Experiences with first-time adoption in Europe. Accounting in Europe, 3 (1), 23-26.

Hoogervorst, H. (2013), 'Breaking the boilerplate' <http:// www.ifrs.org/Alerts/Conference/Documents/2013/HH-Amsterdam-June-2013.pdf>, accessed March 2014.

Hope, O-K. (2003a), 'Disclosure practices, enforcement of accounting standards and analysts' forecast accuracy: an international study', Journal of Accounting Research, Vol. 41, No. 2, pp. 235-272.

Hope, O-K. (2003b), 'Accounting policy disclosures and analysts' forecasts', Contemporary Accounting Research, Vol. 20, No. 2, pp. 295-321.

Horton, J., Serafeim, G. and Serafeim, I. (2013) 'Does Mandatory IFRS Adoption Improve the Information Environment?' Contemporary Accounting Research, Vol. 30, No. 1 (Spring 2013), pp. 388-423

Hussainey, K. and Mouselli, S. (2010), 'Disclosure quality and stock returns in the UK', Journal of Applied Accounting Research, Vol. 11, No. 2, pp.154 - 174. 
Hussainey, K. and Walker, M. (2009), 'The effects of voluntary disclosure policy and dividend propensity on prices leading earnings', Accounting and Business Research, Vol. 39, No. 1 , pp. 37-55.

IASB (2013), 'Disclosure initiative' <http://www.ifrs.org/ Alerts/PressRelease/Pages/IASBannounces-new-staff-group-to-focus-on-Disclosure-Initiative-October-2013.aspx >.

ICAEW (Institute of Chartered Accountants in England and Wales) (2007), EU Implementation of IFRS and the Fair Value Directive <http://ec.europa.eu/internal_market/accounting/ docs/studies/2007eu_implementation_of_ifrs.pdf >, accessed 10 March 2014.

ICAS and NZICA (Institute of Chartered Accountants of Scotland and the New Zealand Institute of Chartered Accountants) (2011), Losing the Excess Baggage - Reducing Disclosures in Financial Statements to What's Important.

Ineum Consulting, 2008. Evaluation of the application of IFRS in the 2006 Financial Statements of European Companies. Available from http://ec.europa.eu/internal_market/accounting/docs/studies/2009-report_en.pdf [Accessed 31 March 2014].

Kang, T. and Pang, Y.H. (2005), 'Economic Development and the Value-Relevance of Accounting Information - A Disclosure Transparency Perspective', Review of Accounting and Finance, Vol. 4, No. 1, pp. 5-31.

Kohlbeck, M. and Mayhew, B.W. (2010), "Valuation of firms that disclose related party transactions', Journal of Accounting and Public Policy, Vol. 29, No. 2, pp. 115-137.

Leuz, C. and Wysocki, P. (2008), 'Economic consequences of financial reporting and disclosure regulation: a review and suggestions for future research', Working Paper.

Leuz, C. and Wysocki, P., 2016. The economics of disclosure and financial reporting regulation: evidence and suggestions for future research. Journal of Accounting Research, 54 (2), 525-622.

MacKinnon, J. and White, H. (1985), 'Some heteroskedasticity-consistent covariance matrix estimators with improved finite sample properties', Journal of Econometrics, Vol. 29, pp. 305-325.

Mazzi, F. André P. D.Dionysiou \& Tsalavoutas, I. (2017). Goodwill related mandatory disclosures and cost of equity capital, Accounting and Business Research, 47(3), pp. 268312.

Mazzi, F. Liberatore, G. \& Tsalavoutas, I. (2016). Insights on CFOs perceptions regarding IAS 36 reporting, Accounting in Europe, 13(3), pp. 353-379.

McInnis, John M. and Monsen, Brian R., Are the Recorded Values of Acquired Intangible Assets Indicative of Their Future Payoffs? (April 2017). Available at SSRN: https://ssrn.com/abstract $=2956669$

Myers, J. (1999), 'Implementing residual income valuation with linear information dynamics', The Accounting Review, Vol., 74, No. 1, pp. 1-28.

Ohlson, J.A. (1995), 'Earnings, book values, and dividends in security valuation' Contemporary Accounting Research, Vol. 11, No. 2, pp. 661-687.

Ohlson, J.A. (2001), 'Earnings, book values, and dividends in equity valuation: an empirical perspective', Contemporary Accounting Research, Vol. 18, No. 1, pp. 107-120.

Pownall, G. and Schipper, K. (1999), 'Implications of accounting research for the SEC's consideration of International Accounting Standards for U.S. securities offerings', Accounting Horizons, Vol. 13, No. 3, pp. 259-280.

Preiato, J.P., Brown, P.R. and Tarca, A. (2013), 'Mandatory Adoption of IFRS and Analysts' Forecasts: How Much Does Enforcement Matter?', UNSW Australian School of Business Research Paper <http://ssrn.com/abstract=1499625>, accessed 10 March 2014. 
Ramanna, K., and R. Watts. 2012. Evidence on the use of unverifiable estimates in required goodwill impairment. Review of Accounting Studies 17 (4): 749-780.

Schipper, K. (2007), Required disclosures in Financial Reports, The Accounting Review, Vol. 82, No. 2, pp. 301-326.

SEC (Securities and Exchange Committee) (2007), 'Staff Observations in the Review of IFRS Financial Statements' <http://www.sec.gov/divisions/corpfin/ifrs_staffobservations.htm>, accessed 10 March 2014.

Sinkin, C., Wright, C.J., and Burnett, R. D. (2008). Eco-efficiency and firm value, Journal of Accounting and Public Policy, 27, 167-176.

Slack, R. and Shrives, P. (2010), 'Voluntary disclosure narratives: more research or time to reflect?', Journal of Applied Accounting Research, Vol. 11, No. 2, pp. 84 - 89.

Tan, H., Wang, S. and Welker, M. (2011) 'Analyst following and forecast accuracy after mandated IFRS adoptions' Journal of Accounting Research, Vol. 49, No. 5, pp. 1307 57.

Teixeira, A., 2014. The International Accounting Standards Board and Evidence-Informed Standard-Setting. Accounting in Europe, 11(1), 5-12.

Tsalavoutas, I. (2011), 'Transition to IFRS and Compliance with Mandatory Disclosure Requirements: What is the Signal?', Advances in Accounting, 27 (2): 390-405.

Tsalavoutas, I. and Dionysiou, D. (2014) 'Value relevance of IFRS mandatory disclosure requirements', Journal of Applied Accounting Research, Vol. 15, No. 1. pp. 22-42.

Tsalavoutas, I., André, P. and Dionysiou, D. (2014) 'Worldwide application of IFRS 3, IAS 38 and IAS 36, related disclosures, and determinants of non-compliance', Association of Chartered Certified Accountants (ACCA) Research Report (134), London.

Tsalavoutas, I., André, P. and Evans, L. (2012), 'The transition to IFRS and the value relevance of financial statements in Greece, The British Accounting Review, Vol. 44, pp. 262-277.

Tsalavoutas, I., Evans, L. and Smith, M. (2010), 'Comparison of Two Methods for Measuring Compliance with IFRS Mandatory Disclosure Requirements', Journal of Applied Accounting Research, Vol. 11, No. 3, pp. 213 - 228.

Verrecchia, R.E. (2001), 'Essays on disclosure', Journal of Accounting and Economics, Vol. 32, No 1-3, pp. 97-180.

White, H. (1980), 'A heteroskedasticity-consistent covariance matrix estimator and a direct test for heteroskedasticity', Econometrica, Vol. 48, No. 4, pp. 817-838. 
Table 1: Number of companies examined across countries and industries.

\begin{tabular}{|c|c|c|c|c|c|c|c|c|c|c|}
\hline Country & $\begin{array}{c}\text { Basic } \\
\text { materials }\end{array}$ & $\begin{array}{l}\text { Consumer } \\
\text { Goods }\end{array}$ & $\begin{array}{l}\text { Consumer } \\
\text { Services }\end{array}$ & Healthcare & Industrials & $\begin{array}{c}\text { Oil \& } \\
\text { Gas }\end{array}$ & Technology & Telecoms & Utilities & Total \\
\hline AUSTRIA & 1 & 0 & 0 & 1 & 8 & 2 & 0 & 1 & 2 & 15 \\
\hline BELGIUM & 2 & 1 & 3 & 2 & 1 & 0 & 0 & 2 & 0 & 11 \\
\hline DENMARK & 0 & 3 & 0 & 5 & 4 & 1 & 0 & 0 & 0 & 13 \\
\hline FINLAND & 5 & 1 & 2 & 1 & 7 & 1 & 2 & 1 & 1 & 21 \\
\hline FRANCE & 1 & 10 & 10 & 2 & 10 & 2 & 3 & 1 & 3 & 42 \\
\hline GERMANY & 5 & 7 & 3 & 3 & 6 & 0 & 2 & 1 & 2 & 29 \\
\hline GREECE & 1 & 0 & 1 & 0 & 3 & 1 & 0 & 1 & 1 & 8 \\
\hline IRELAND & 0 & 4 & 3 & 2 & 3 & 0 & 0 & 0 & 0 & 12 \\
\hline ITALY & 1 & 5 & 1 & 0 & 3 & 2 & 1 & 1 & 6 & 20 \\
\hline NETHERLANDS & 3 & 3 & 2 & 0 & 4 & 2 & 2 & 1 & 0 & 17 \\
\hline NORWAY & 2 & 1 & 1 & 0 & 2 & 8 & 0 & 1 & 0 & 15 \\
\hline PORTUGAL & 4 & 3 & 0 & 0 & 4 & 1 & 0 & 2 & 3 & 17 \\
\hline SPAIN & 1 & 1 & 1 & 1 & 9 & 3 & 1 & 1 & 5 & 23 \\
\hline SWEDEN & 3 & 2 & 2 & 1 & 8 & 0 & 1 & 2 & 0 & 19 \\
\hline SWITZERLAND & 3 & 5 & 1 & 6 & 10 & 1 & 1 & 1 & 0 & 28 \\
\hline UK & 10 & 11 & 21 & 3 & 17 & 7 & 6 & 4 & 4 & 83 \\
\hline TOTAL & 42 & 57 & 51 & 27 & 99 & 31 & 19 & 20 & 27 & 373 \\
\hline
\end{tabular}

Industries are defined as in the Industry Classification Benchmark (ICB) Level 2. 
Table 2: Frequency and distribution of compliance scores.

\begin{tabular}{|c|c|c|c|c|c|c|c|c|}
\hline \multirow{2}{*}{$\begin{array}{c}\text { Compliance } \\
\text { score }(\%)\end{array}$} & \multicolumn{2}{|c|}{ IAS 36_CS } & \multicolumn{2}{|c|}{ IAS 38_CS } & \multicolumn{2}{|c|}{ Aver_1 } & \multicolumn{2}{|c|}{ Aver_2 } \\
\hline & 5 & $1.34 \%$ & 0 & $0.00 \%$ & 0 & $0.00 \%$ & 0 & $0.00 \%$ \\
\hline 0.10-0.19 & 1 & $0.27 \%$ & 0 & $0.00 \%$ & 0 & $0.00 \%$ & 0 & $0.00 \%$ \\
\hline $0.20-0.29$ & 1 & $0.27 \%$ & 0 & $0.00 \%$ & 1 & $0.27 \%$ & 0 & $0.00 \%$ \\
\hline $0.30-0.39$ & 5 & $1.34 \%$ & 2 & $0.54 \%$ & 1 & $0.27 \%$ & 3 & $0.80 \%$ \\
\hline $0.40-0.49$ & 9 & $2.41 \%$ & 6 & $1.61 \%$ & 8 & $2.14 \%$ & 3 & $0.80 \%$ \\
\hline $0.50-0.59$ & 23 & $6.17 \%$ & 9 & $2.41 \%$ & 9 & $2.41 \%$ & 15 & $4.02 \%$ \\
\hline $0.60-0.69$ & 17 & $4.56 \%$ & 44 & $11.80 \%$ & 33 & $8.85 \%$ & 29 & $7.77 \%$ \\
\hline $0.70-0.79$ & 70 & $18.77 \%$ & 17 & $4.56 \%$ & 67 & $17.96 \%$ & 65 & $17.43 \%$ \\
\hline $0.80-0.89$ & 87 & $23.32 \%$ & 122 & $32.71 \%$ & 117 & $31.37 \%$ & 123 & $32.98 \%$ \\
\hline $0.90-100$ & 155 & $41.55 \%$ & 173 & $46.38 \%$ & 137 & $36.73 \%$ & 135 & $36.19 \%$ \\
\hline$N$ & 373 & $100.0 \%$ & 373 & $100.0 \%$ & 373 & $100.0 \%$ & 373 & \\
\hline Mean & 0.819 & & 0.859 & & 0.839 & & 0.840 & \\
\hline $\mathrm{SD}$ & 0.189 & & 0.155 & & 0.134 & & 0.129 & \\
\hline Min & 0.000 & & 0.333 & & 0.250 & & 0.333 & \\
\hline Median & 0.857 & & 0.900 & & 0.857 & & 0.857 & \\
\hline Max & 1.000 & & 1.000 & & 1.000 & & 1.000 & \\
\hline
\end{tabular}

The table presents compliance levels with IAS 36 and IAS 38 separately as well as on average. Aver_l assumes that each standard is of equal importance, and thus, each standard has equal weight. Aver_ 2 assumes each mandated item is of equal importance, irrespective of how many items a standard mandates and in which standard the item is included. $N$ stands for number of firms, while $\mathrm{N} \%$ stands for number of firms as a percentage of the total number of firms in the sample (i.e., 373). 
Table 3: Paragraphs in IAS 36 and IAS 38 for which high non-compliance is observed

\begin{tabular}{|c|c|c|c|}
\hline \multicolumn{4}{|c|}{ IAS 36 - Impairment of Assets } \\
\hline Paragraph & Sub-paragraph & $\mathbf{N}$ & \% compliance \\
\hline 129 & $129-a$ & & \\
\hline $\begin{array}{l}\text { An entity that reports segment information } \\
\text { in accordance with IFRS } 8 \text { shall disclose the } \\
\text { following for each reportable segment }\end{array}$ & $\begin{array}{l}\text { the amount of impairment losses recognised in profit or loss and in other comprehensive income } \\
\text { during the period } \\
129-b\end{array}$ & 254 & $59.4 \%$ \\
\hline 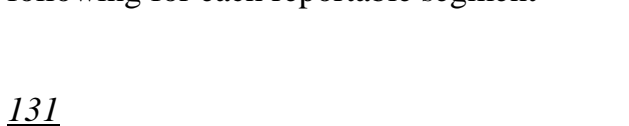 & $\begin{array}{l}\text { the amount of reversals of impairment losses recognised in profit or loss and in other } \\
\text { comprehensive income during the period. } \\
131-b\end{array}$ & 73 & $42.5 \%$ \\
\hline $\begin{array}{l}\text { An entity shall disclose the following } \\
\text { information for the aggregate and the }\end{array}$ & $\begin{array}{l}\text { the main events and circumstances that led to the recognition of these impairment losses and } \\
\text { reversals of impairment losses }\end{array}$ & 250 & 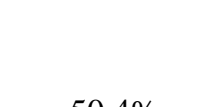 \\
\hline & $\begin{array}{l}\frac{134-a}{\text { the carrying amount of goodwill allocated to the unit (group of units) }} \\
\underline{134-b}\end{array}$ & 355 & $79.4 \%$ \\
\hline 134 & $\begin{array}{l}\text { the carrying amount of intangible assets with indefinite useful lives allocated to the unit (group } \\
\text { of units). }\end{array}$ & 90 & $50.0 \%$ \\
\hline $\begin{array}{l}\text { An entity shall disclose the information } \\
\text { required by (a)-(f) for each cash-generating }\end{array}$ & $\frac{134-d}{\text { if the unit's (group of units') recoverable amount is based on value in use }}$ & & \\
\hline $\begin{array}{l}\text { unit (group of units) for which the carrying } \\
\text { amount of goodwill or intangible assets with } \\
\text { indefinite useful lives allocated to that unit } \\
\text { (group of units) is significant in comparison }\end{array}$ & $\begin{array}{l}\frac{134-d-i}{\text { a description of each key assumption on which management has based its cash flow projections }} \\
\text { for the period covered by the most recent budgets/forecasts. Key assumptions are those to which } \\
\text { the unit's (group of units') recoverable amount is most sensitive }\end{array}$ & 332 & $87.7 \%$ \\
\hline $\begin{array}{l}\text { with the entity's total carrying amount of } \\
\text { goodwill or intangible assets with indefinite } \\
\text { useful lives. }\end{array}$ & $\begin{array}{l}\text { 134-d-ii } \\
\text { a description of management's approach to determining the value(s) assigned to each key } \\
\text { assumption, whether those value(s) reflect past experience or, if appropriate, are consistent with } \\
\text { external sources of information, and, if not, how and why they differ from past experience or } \\
\text { external sources of information }\end{array}$ & 332 & $83.7 \%$ \\
\hline
\end{tabular}




\begin{tabular}{|c|c|c|c|}
\hline \multicolumn{4}{|c|}{ IAS 36 - Impairment of Assets } \\
\hline Paragraph & Sub-paragraph & $\mathbf{N}$ & \% compliance \\
\hline & $134-d-i i i$ & 332 & $87.6 \%$ \\
\hline & $\begin{array}{l}\text { the period over which management has projected cash flows based on financial budgets/forecasts } \\
\text { approved by management and, when a period greater than five years is used for a cash-generating } \\
\text { unit (group of units), an explanation of why that longer period is justified } \\
\underline{134-d-i v}\end{array}$ & & \\
\hline & $\begin{array}{l}\text { the growth rate used to extrapolate cash flow projections beyond the period covered by the most } \\
\text { recent budgets/forecasts, and the justification for using any growth rate that exceeds the long-term } \\
\text { average growth rate for the products, industries, or country or countries in which the entity } \\
\text { operates, or for the market to which the unit (group of units) is dedicated. }\end{array}$ & 332 & $87.6 \%$ \\
\hline \multicolumn{4}{|c|}{ IAS 38 - Intangible Assets } \\
\hline Paragraph & Sub-paragraph & $\mathbf{N}$ & \% compliance \\
\hline \multirow{8}{*}{$\begin{array}{l}\frac{118}{\text { An entity shall disclose the following for }} \\
\text { each class of intangible assets, } \\
\text { distinguishing between internally generated } \\
\text { intangible assets and other intangible assets: }\end{array}$} & $\underline{118-a}$ & & \\
\hline & whether the useful lives are indefinite or finite and, if finite, the useful lives or the amortisation & 373 & $82.0 \%$ \\
\hline & rates used; & & \\
\hline & 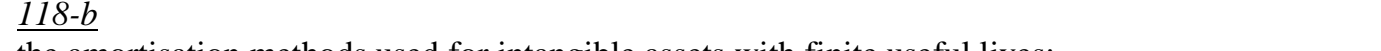 & 369 & $81.3 \%$ \\
\hline & $\begin{array}{l}\text { the amortisation methods used for intangible assets with finite useful lives; } \\
\underline{118-d}\end{array}$ & & 01.510 \\
\hline & $\begin{array}{l}\text { the line item(s) of the statement of comprehensive income in which any amortisation of intangible } \\
\text { assets is included; }\end{array}$ & 367 & $81.7 \%$ \\
\hline & $\underline{122-a}$ & & \\
\hline & $\begin{array}{l}\text { for an intangible asset assessed as having an indefinite useful life, the carrying amount of that asset } \\
\text { and the reasons supporting the assessment of an indefinite useful life. In giving these reasons, the } \\
\text { entity shall describe the factor(s) that played a significant role in determining that the asset has an } \\
\text { indefinite useful life. }\end{array}$ & 107 & $56.1 \%$ \\
\hline
\end{tabular}


Table 4 - Descriptive statistics for dependent and independent variables

\begin{tabular}{|c|c|c|c|c|c|}
\hline Variables & Mean & St. dev & p25 & Median & p75 \\
\hline \multicolumn{6}{|l|}{ Dependent } \\
\hline$M V$ & 1.07 & 0.98 & 0.46 & 0.81 & 1.33 \\
\hline Disper & 0.07 & 0.12 & 0.00 & 0.01 & 0.04 \\
\hline Accur & -0.08 & 0.16 & -0.05 & -0.01 & 0.00 \\
\hline \multicolumn{6}{|l|}{ Independent } \\
\hline$B V E$ & 0.41 & 0.16 & 0.29 & 0.41 & 0.51 \\
\hline$N I$ & 0.06 & 0.10 & 0.03 & 0.05 & 0.08 \\
\hline SIZE & 15.64 & 1.25 & 14.85 & 15.58 & 16.40 \\
\hline Impair & 0.69 & 0.46 & 0.00 & 1.00 & 1.00 \\
\hline Int & 0.27 & 0.41 & 0.09 & 0.21 & 0.40 \\
\hline AnFol & 2.87 & 0.56 & 2.67 & 3.00 & 3.23 \\
\hline Hor & 3.93 & 0.30 & 3.71 & 3.99 & 4.11 \\
\hline Loss & 0.05 & 0.21 & 0.00 & 0.00 & 0.00 \\
\hline NI_Ch & 0.59 & 4.39 & 0.07 & 0.30 & 0.79 \\
\hline$A W C A$ & 0.04 & 0.05 & 0.01 & 0.02 & 0.04 \\
\hline Readability & 5.12 & 0.44 & 4.82 & 5.10 & 5.43 \\
\hline US_List & 0.23 & 0.42 & 0.00 & 0.00 & 0.00 \\
\hline Mkt_Dev & 0.89 & 0.58 & 0.44 & 0.76 & 1.38 \\
\hline Enforce & 19.35 & 3.53 & 16.00 & 20.00 & 22.00 \\
\hline Ind & 0.66 & 0.48 & 0.00 & 1.00 & 1.00 \\
\hline
\end{tabular}

$M V_{j t}$ is the market value of a company $j$ four months after the publication of the financial statements relating to the financial period (WC08001); Disper $_{j}$ is the standard deviation of analysts' forecasts (I/B/E/S) (last I/B/E/S forecast prior to the EPS announcement), scaled by share price; $A c c u r_{j}$ is the absolute value of the difference between mean I/B/E/S forecast (last I/B/E/S forecast prior to the EPS announcement) and actual EPS, scaled by stock price and multiply $-1 ; B V E_{j}$ is the book value of net assets at the end of the financial period (WC03501); $N I_{j}$ is the net profit after tax for the financial period (WC01751); $C S_{j}$ is the mandatory disclosure compliance score; $S I Z E_{j t}$ is natural logarithm of the market value of a company $j$ four months after the publication of the financial statements (WC08001); Impair $r_{j}$ is an indicator variable that takes 1 if an impairment is reported and 0 otherwise (hand collected); Int $t_{j}$ is the ratio between total intangible assets, including goodwill, and total assets (hand collected); $\mathrm{AnFol}_{j}$ is the number of analysts contributing to the forecast as reported by $\mathrm{I} / \mathrm{B} / \mathrm{E} / \mathrm{S} ; \mathrm{Hor}_{j}$ is measured as the number of months from the forecast date until the company releases its actual earnings (I/B/E/S); Loss $j$ is an indicator variable for loss making companies; $N I_{-} C h_{j}$ is the absolute value of the change in earnings between current earnings and that of the previous year, scaled by last year's earnings; $A W C A_{j}$ is the absolute value of abnormal working capital accruals scaled by total assets; Readability is the logarithmic transformation of annual report page count; the vector; $U S_{-}$List $_{j}$ is a binary variable that takes a value of one when the firm is listed in the US and zero otherwise (identifed via DataStream); $M k t_{-} D e v_{j}$ is the market capitalisation of listed companies as a percentage of GDP for each country (World Bank); Enforce $_{j}$ is an index combining the level of activity of independent enforcement bodies and important features of the audit environment likely to affect the quality of enforcement of financial reporting requirements by auditors in a country (Preiato et al. 2013) where the higher the index the stronger the enforcement environment; $I n d_{j}$ takes a value of one when a firm is categorised into 'manufacturing' on the basis of their industry participation, according to ICB, and zero otherwise. 
Table 5 - Pearson's correlation coefficients

\begin{tabular}{|c|c|c|c|c|c|c|c|c|c|c|c|c|c|c|}
\hline Variables & Aver_l & Aver_2 & IAS36_CS & IAS38_CS & $M V$ & $B V E$ & $N I$ & Disper & Accur & SIZE & Impair & Int & AnFol & $\mathrm{Hor}$ \\
\hline $\begin{array}{l}\text { Aver_1 } \\
\text { Aver_2 }\end{array}$ & $\begin{array}{c}1 \\
0.956 * * *\end{array}$ & 1 & & & & & & & & & & & & \\
\hline IAS36_CS & $0.821 * * *$ & $0.806 * * *$ & 1 & & & & & & & & & & & \\
\hline IAS38_CS & $0.719 * * *$ & $0.661 * * *$ & $0.193 * * *$ & 1 & & & & & & & & & & \\
\hline$M V^{-}$ & $0.146^{* * *}$ & $0.136^{* *}$ & $0.103 * *$ & $0.125^{* *}$ & 1 & & & & & & & & & \\
\hline$B V E$ & 0.074 & 0.056 & 0.065 & 0.048 & $0.442 * * *$ & 1 & & & & & & & & \\
\hline$N I$ & 0.056 & 0.057 & 0.008 & $0.087 *$ & $0.374 * * *$ & $0.209 * * *$ & 1 & & & & & & & \\
\hline Disper & $0.192 * * *$ & $0.197 * * *$ & $0.196 * * *$ & $0.092 *$ & -0.027 & $-0.135 * * *$ & $0.092 *$ & 1 & & & & & & \\
\hline Accur & $-0.183 * * *$ & $-0.186^{* * *}$ & $-0.178 * * *$ & $-0.097 *$ & 0.011 & $0.087^{*}$ & -0.085 & $-0.869 * * *$ & 1 & & & & & \\
\hline SIZE & -0.019 & 0.016 & 0.073 & $-0.122 * *$ & $0.103 * *$ & 0.056 & $0.118^{* *}$ & -0.080 & 0.083 & 1 & & & & \\
\hline Impair & -0.053 & $-0.088 *$ & 0.015 & $-0.109 * *$ & $-0.186 * * *$ & $-0.090 *$ & -0.075 & -0.018 & 0.001 & $0.219 * * *$ & 1 & & & \\
\hline Int & 0.068 & 0.083 & 0.059 & 0.045 & $0.157 * * *$ & 0.053 & $0.236^{* * *}$ & 0.056 & -0.026 & 0.009 & $-0.128 * *$ & 1 & & \\
\hline AnFol & 0.048 & $0.092^{*}$ & $0.158 * * *$ & $-0.110 * *$ & 0.048 & -0.013 & 0.061 & 0.053 & -0.029 & $0.651 * * *$ & $0.115 * * *$ & 0.062 & 1 & \\
\hline Hor & $-0.164 * * *$ & $-0.165 * * *$ & $-0.174 * * *$ & -0.071 & $-0.165 * * *$ & -0.088 & -0.071 & 0.039 & -0.050 & $-0.239 * * *$ & -0.068 & 0.059 & $-0.237 * * *$ & 1 \\
\hline Loss & 0.015 & -0.001 & -0.001 & 0.027 & $-0.087 *$ & -0.039 & $-0.371 * * *$ & 0.060 & $-0.094 *$ & $-0.168 * * *$ & $0.124 * *$ & -0.073 & $-0.138 * * *$ & -0.02 \\
\hline NI_Ch & $-0.130 * *$ & $-0.102 * *$ & -0.069 & $-0.139 * * *$ & 0.025 & 0.084 & $0.196 * * *$ & -0.057 & 0.037 & 0.057 & 0.004 & 0.007 & 0.062 & 0.00 \\
\hline$M \overline{k t}$ DDev & $0.262^{* * * *}$ & $0.275^{* * *}$ & $0.278^{* * *}$ & $0.112 * *$ & $0.247 * * *$ & $0.135^{* * *}$ & $0.198 * * *$ & $0.336 * * *$ & $-0.296^{* * *}$ & $0.158 * *$ & -0.080 & -0.015 & $0.159 * * *$ & -0.163 \\
\hline Enforce & $0.248 * * *$ & $0.274 * * *$ & $0.321 * * *$ & 0.035 & $0.116^{* *}$ & 0.042 & $0.165^{* * *}$ & $0.543 * * *$ & $-0.479 * * *$ & $0.281 * * *$ & -0.015 & 0.019 & $0.204 * * *$ & 0.04 \\
\hline$A W C A$ & 0.064 & 0.074 & 0.049 & 0.051 & 0.068 & $0.096^{*}$ & 0.033 & -0.032 & 0.007 & $-0.179 * * *$ & 0.030 & 0.029 & $-0.095^{*}$ & 0.006 \\
\hline Readability & $-0.136 * * *$ & $-0.119 * *$ & -0.077 & $-0.139 * * *$ & $-0.210 * * *$ & $-0.196 * * *$ & $-0.135 * * *$ & $-0.235^{* * *}$ & $0.211 * * *$ & $0.271 * * *$ & $0.200 * * *$ & -0.047 & $0.115^{* *}$ & $0.111^{*}$ \\
\hline Ind & 0.035 & 0.045 & 0.025 & 0.029 & -0.015 & $0.116^{* *}$ & -0.010 & $-0.096^{* *}$ & $0.100^{*}$ & -0.042 & 0.002 & $-0.136 * * *$ & $-0.106^{* *}$ & -0.06 \\
\hline US_List & $0.100 * *$ & $0.102 * *$ & 0.059 & $0.101 * *$ & -0.006 & -0.043 & -0.002 & 0.047 & -0.058 & 0.069 & 0.047 & $0.103 * *$ & 0.007 & -0.02 \\
\hline
\end{tabular}

Table 5 - Continued

\begin{tabular}{lccccccc}
\hline Variable & Loss & NI_Ch & Mkt_Dev & Enforce & Ind & AWCA & Readability \\
\hline Loss & 1 & & & & & & \\
NI_Ch & -0.077 & 1 & & & & & \\
Mkt_Dev & -0.024 & 0.001 & 1 & & & & \\
Enforce & -0.050 & 0.050 & $0.342^{* *}$ & 1 & & 1 \\
Ind & 0.042 & $-0.096^{*}$ & -0.030 & $-0.087^{*}$ & 1 & & 1 \\
AWCA & -0.056 & 0.059 & $-0.165^{*}$ & $-0.100^{*}$ & -0.061 & 1 & -0.065 \\
Readability & 0.057 & 0.043 & 0.021 & -0.035 & -0.031 & -0.020 & 1 \\
US_List & 0.029 & -0.011 & 0.011 & 0.084 & -0.045 & 0.049 & \\
\hline
\end{tabular}

$\mathrm{N}=373$. Variables' definitions are discussed in Table $4 .{ }^{* * *}, * *$ and $*$ indicate statistical significance at the $1 \%, 5 \%$ and $10 \%$ levels, respectively. 
Table 6: Multivariate analyses

\begin{tabular}{|c|c|c|c|c|c|c|c|c|c|}
\hline \multirow[b]{2}{*}{ Variables } & \multicolumn{3}{|c|}{$\begin{array}{l}\text { Value relevance } \\
\text { (H1) }\end{array}$} & \multicolumn{3}{|c|}{$\begin{array}{l}\text { Analysts' forecast dispersion } \\
\text { (H2) }\end{array}$} & \multicolumn{3}{|c|}{$\begin{array}{l}\text { Analysts' forecast accuracy } \\
\text { (H3) }\end{array}$} \\
\hline & Aver_l & Aver_2 & $\begin{array}{c}\text { IAS36_CS } \\
\& \\
\text { IAS38_CS }\end{array}$ & Aver_l & Aver_2 & $\begin{array}{c}I A S 36 \_C S \\
\& \\
I A S 38 \_C S\end{array}$ & Aver_l & Aver_2 & $\begin{array}{c}\text { IAS36_CS } \\
\& \\
\text { IAS38_CS }\end{array}$ \\
\hline Intercept & $\begin{array}{l}-0.048 \\
(-0.11)\end{array}$ & $\begin{array}{l}-0.068 \\
(-0.15)\end{array}$ & $\begin{array}{l}0.043 \\
(0.09)\end{array}$ & $\begin{array}{c}0.349 \\
(2.97)^{* * *}\end{array}$ & $\begin{array}{c}0.337 \\
(2.90)^{* * *}\end{array}$ & $\begin{array}{c}0.348 \\
(3.31)^{* * *}\end{array}$ & $\begin{array}{l}-0.111 \\
(-0.88)\end{array}$ & $\begin{array}{l}-0.104 \\
(-0.84)\end{array}$ & $\begin{array}{l}-0.144 \\
(-1.05)\end{array}$ \\
\hline$B V E$ & $\begin{array}{c}0.666 \\
(3.52)^{* * *}\end{array}$ & $\begin{array}{c}0.676 \\
(3.57)^{* * *}\end{array}$ & $\begin{array}{c}0.663 \\
(3.52)^{* * *}\end{array}$ & & & & & & \\
\hline$N I$ & $\begin{array}{c}7.409 \\
(9.12)^{* * *}\end{array}$ & $\begin{array}{c}7.398 \\
(9.11)^{* * *}\end{array}$ & $\begin{array}{c}7.429 \\
(9.20)^{* * *}\end{array}$ & & & & & & \\
\hline$C S$ & $\begin{array}{c}\mathbf{0 . 4 5 2} \\
(\mathbf{2 . 5 1})^{* *}\end{array}$ & $\begin{array}{c}\mathbf{0 . 5 2 0} \\
(\mathbf{2 . 8 0})^{* * *}\end{array}$ & & $\begin{array}{c}-0.066 \\
(-2.32)^{* * *}\end{array}$ & $\begin{array}{c}-0.062 \\
(-2.06)^{* * * *}\end{array}$ & & $\begin{array}{l}0.053 \\
(1.62)\end{array}$ & $\begin{array}{l}0.053 \\
(1.48)\end{array}$ & \\
\hline IAS36_CS & & & $\begin{array}{c}0.328 \\
(2.94)^{* * *}\end{array}$ & & & $\begin{array}{c}-0.044 \\
(-2.39)^{* *}\end{array}$ & & & $\begin{array}{c}\mathbf{0 . 0 5 5} \\
(\mathbf{1 . 9 9})^{* *}\end{array}$ \\
\hline IAS38_CS & & & $\begin{array}{l}0.098 \\
(0.60)\end{array}$ & & & $\begin{array}{l}-0.015 \\
(-0.65)\end{array}$ & & & $\begin{array}{l}-0.009 \\
(-0.31)\end{array}$ \\
\hline Mkt_Dev & $\begin{array}{c}0.166 \\
(3.04)^{* * *}\end{array}$ & $\begin{array}{c}0.164 \\
(3.01)^{* * *}\end{array}$ & $\begin{array}{c}0.161 \\
(2.92)^{* * *}\end{array}$ & $\begin{array}{c}0.026 \\
(3.84)^{* * *}\end{array}$ & $\begin{array}{c}0.026 \\
(3.80)^{* * *}\end{array}$ & $\begin{array}{c}0.030 \\
(4.77)^{* * *}\end{array}$ & $\begin{array}{c}-0.038 \\
(-3.57)^{* * *}\end{array}$ & $\begin{array}{c}-0.038 \\
(-3.57)^{* * *}\end{array}$ & $\begin{array}{c}-0.029 \\
(-3.69)^{* * *}\end{array}$ \\
\hline Enforce & $\begin{array}{l}0.007 \\
(0.83)\end{array}$ & $\begin{array}{l}0.006 \\
(0.83)\end{array}$ & $\begin{array}{l}0.005 \\
(0.56)\end{array}$ & $\begin{array}{c}0.006 \\
(3.77) * * *\end{array}$ & $\begin{array}{c}0.006 \\
(3.78) * * *\end{array}$ & $\begin{array}{c}0.005 \\
(4.20)^{* * *}\end{array}$ & $\begin{array}{c}-0.005 \\
(-3.22)^{* * *}\end{array}$ & $\begin{array}{c}-0.005 \\
(-3.24)^{* * *}\end{array}$ & $\begin{array}{c}-0.006 \\
(-3.30)^{* * *}\end{array}$ \\
\hline$A W C A$ & $\begin{array}{l}0.120 \\
(0.24)\end{array}$ & $\begin{array}{l}0.093 \\
(0.19)\end{array}$ & $\begin{array}{l}0.114 \\
(0.23)\end{array}$ & $\begin{array}{l}-0.060 \\
(-0.92)\end{array}$ & $\begin{array}{l}-0.058 \\
(-0.89)\end{array}$ & $\begin{array}{l}-0.059 \\
(-1.06)\end{array}$ & $\begin{array}{l}0.011 \\
(0.14)\end{array}$ & $\begin{array}{l}0.009 \\
(0.11)\end{array}$ & $\begin{array}{l}0.029 \\
(0.35)\end{array}$ \\
\hline Readability & $\begin{array}{l}-0.096 \\
(-1.32)\end{array}$ & $\begin{array}{l}-0.098 \\
(-1.36)\end{array}$ & $\begin{array}{l}-0.098 \\
(-1.35)\end{array}$ & $\begin{array}{l}-0.006 \\
(-0.77)\end{array}$ & $\begin{array}{l}-0.006 \\
(-0.73)\end{array}$ & $\begin{array}{l}-0.007 \\
(-0.96)\end{array}$ & $\begin{array}{l}0.006 \\
(0.67)\end{array}$ & $\begin{array}{l}0.005 \\
(0.64)\end{array}$ & $\begin{array}{l}0.013 \\
(1.12)\end{array}$ \\
\hline SIZE & & & & $\begin{array}{c}-0.027 \\
(-4.32)^{* * *}\end{array}$ & $\begin{array}{c}-0.027 \\
(-4.30) * * *\end{array}$ & $\begin{array}{c}-0.028 \\
(-5.39)^{* * *}\end{array}$ & $\begin{array}{c}0.020 \\
(3.31)^{* * *}\end{array}$ & $\begin{array}{c}0.019 \\
(3.30)^{* * *}\end{array}$ & $\begin{array}{c}0.022 \\
(3.49)^{* * *}\end{array}$ \\
\hline Impair & & & & $\begin{array}{c}0.029 \\
(2.84)^{* * *}\end{array}$ & $\begin{array}{c}0.028 \\
(2.73)^{* * *}\end{array}$ & $\begin{array}{c}0.029 \\
(3.08)^{* * *}\end{array}$ & $\begin{array}{c}-0.031 \\
(-2.70) * * *\end{array}$ & $\begin{array}{c}-0.030 \\
(-2.64) * * *\end{array}$ & $\begin{array}{c}-0.038 \\
(-2.93)^{* * *}\end{array}$ \\
\hline Int & & & & $\begin{array}{l}0.010 \\
(1.58)\end{array}$ & $\begin{array}{l}0.010 \\
(1.58)\end{array}$ & $\begin{array}{c}0.012 \\
(1.80)^{*}\end{array}$ & $\begin{array}{l}-0.009 \\
(-1.29)\end{array}$ & $\begin{array}{l}-0.009 \\
(-1.30)\end{array}$ & $\begin{array}{l}-0.011 \\
(-1.39)\end{array}$ \\
\hline $\mathrm{AnFol}$ & & & & $\begin{array}{c}0.047 \\
(4.35)^{* * *}\end{array}$ & $\begin{array}{c}0.047 \\
(4.40)^{* * *}\end{array}$ & $\begin{array}{c}0.048 \\
(4.48)^{* * *}\end{array}$ & $\begin{array}{c}-0.043 \\
(-3.07)^{* * *}\end{array}$ & $\begin{array}{c}-0.043 \\
(-3.08)^{* * *}\end{array}$ & $\begin{array}{c}-0.048 \\
(-3.24)^{* * *}\end{array}$ \\
\hline Hor & & & & $\begin{array}{l}0.014 \\
(0.84)\end{array}$ & $\begin{array}{l}0.015 \\
(0.88)\end{array}$ & $\begin{array}{l}0.015 \\
(1.04)\end{array}$ & $\begin{array}{c}-0.039 \\
(-1.96)^{* *}\end{array}$ & $\begin{array}{c}-0.039 \\
(-1.98)^{* *}\end{array}$ & $\begin{array}{c}-0.040 \\
(-2.01)^{* *}\end{array}$ \\
\hline Loss & & & & $\begin{array}{l}0.036 \\
(1.30)\end{array}$ & $\begin{array}{l}0.036 \\
(1.31)\end{array}$ & $\begin{array}{l}0.014 \\
(0.65)\end{array}$ & $\begin{array}{l}-0.126 \\
(-1.61)\end{array}$ & $\begin{array}{l}-0.126 \\
(-1.61)\end{array}$ & $\begin{array}{l}-0.121 \\
(-1.56)\end{array}$ \\
\hline NI_Ch & & & & $\begin{array}{c}-0.003 \\
(-2.48) * * *\end{array}$ & $\begin{array}{c}-0.003 \\
(-2.42)^{* * *}\end{array}$ & $\begin{array}{c}-0.002 \\
(-1.68)^{*}\end{array}$ & $\begin{array}{c}0.002 \\
(1.76)^{*}\end{array}$ & $\begin{array}{c}0.002 \\
(1.71)^{*}\end{array}$ & $\begin{array}{c}0.002 \\
(1.83)^{*}\end{array}$ \\
\hline US_List & & & & $\begin{array}{l}-0.001 \\
(-0.07)\end{array}$ & $\begin{array}{l}-0.001 \\
(-0.08)\end{array}$ & $\begin{array}{l}-0.008 \\
(-0.79)\end{array}$ & $\begin{array}{c}0.0001 \\
(0.00)\end{array}$ & $\begin{array}{c}0.0001 \\
(0.00)\end{array}$ & $\begin{array}{l}0.003 \\
(0.20)\end{array}$ \\
\hline Ind & & & & $\begin{array}{c}-0.019 \\
(-1.91)^{*}\end{array}$ & $\begin{array}{c}-0.019 \\
(-1.90)^{*}\end{array}$ & $\begin{array}{l}-0.012 \\
(-1.49)\end{array}$ & $\begin{array}{l}0.009 \\
(0.84)\end{array}$ & $\begin{array}{l}0.009 \\
(0.82)\end{array}$ & $\begin{array}{l}0.006 \\
(0.54)\end{array}$ \\
\hline DLeg_Or & Included & Included & Included & Included & Included & Included & Included & Included & Included \\
\hline$N$ & 359 & 359 & 359 & 359 & 359 & 361 & 352 & 352 & 353 \\
\hline$F$-Stat & $21.12 * * *$ & $21.28 * * *$ & $20.40 * * *$ & $13.44 * * *$ & $13.41 * * *$ & $12.12 * * *$ & $4.03^{* * *}$ & $4.02^{* * *}$ & $3.90^{* * *}$ \\
\hline Adj. $R^{2}$ & 0.54 & 0.54 & 0.54 & 0.57 & 0.56 & 0.59 & 0.34 & 0.34 & 0.35 \\
\hline Max VIF & 2.92 & 2.91 & 2.97 & 3.15 & 3.14 & 3.17 & 3.14 & 3.13 & 3.17 \\
\hline
\end{tabular}

Compliance levels with IAS 36 (IAS36_CS) and IAS 38 (IAS38_CS). Aver_l assumes that each standard is of equal importance, and thus, each standard has equal weight. Aver_2 assumes each mandated item is of equal importance, irrespective of how many items a standard mandates and in which standard the item is included. $M V_{j t}$ is the market value of a company $j$ four months after the publication of the financial statements relating to the financial period (WC08001); Disper $_{j}$ is the standard deviation of analysts' forecasts (I/B/E/S) (last $\mathrm{I} / \mathrm{B} / \mathrm{E} / \mathrm{S}$ forecast prior to the EPS announcement), scaled by share price; Accur $_{j}$ is the absolute value of the difference between mean $\mathrm{I} / \mathrm{B} / \mathrm{E} / \mathrm{S}$ forecast (last $\mathrm{I} / \mathrm{B} / \mathrm{E} / \mathrm{S}$ forecast prior to the EPS announcement) and actual EPS, scaled by stock price [we multiply this variable by -1 so as to be interpreted as accuracy; the higher the better]; $B V E_{j}$ is the book value of net assets at the end of the financial period (WC03501); $N I_{j}$ is the net profit 
after tax for the financial period (WC01751); $C S_{j}$ is the mandatory disclosure compliance score; $S I Z E_{j t}$ is natural logarithm of the market value of a company $j$ four months after the publication of the financial statements (WC08001); Impair is an indicator variable that takes 1 if an impairment is reported and 0 otherwise (hand collected); Int $t_{j}$ is the ratio between total intangible assets, including goodwill, and total assets (hand collected); $A n F o l_{j}$ is the number of analysts contributing to the forecast as reported by $\mathrm{I} / \mathrm{B} / \mathrm{E} / \mathrm{S} ; H_{o r}$ is measured as the number of months from the forecast date until the company releases its actual earnings (I/B/E/S); Loss $_{j}$ is an indicator variable for loss making companies; $N I \_C h_{j}$ is the absolute value of the change in earnings between current earnings and that of the previous year, scaled by last year's earnings; $A W C A_{j}$ is the absolute value of abnormal working capital accruals scaled by total assets; Readability is the logarithmic transformation of annual report page count; the vector; $U S \_L i s t_{j}$ is a binary variable that takes a value of one when the firm is listed in the US and zero otherwise (identifed via DataStream); $M k t \_D e v_{j}$ is the market capitalisation of listed companies as a percentage of GDP for each country (World Bank); Enforce $e_{j}$ is an index combining the level of activity of independent enforcement bodies and important features of the audit environment likely to affect the quality of enforcement of financial reporting requirements by auditors in a country (Preiato et al. 2013) where the higher the index the stronger the enforcement environment; Ind $d_{j}$ takes a value of one when a firm is categorised into 'manufacturing' on the basis of their industry participation, according to ICB, and zero otherwise; DLeg_Or is a set of dummy variables capturing legal systems of French, Scandinavian and German origin (Djankov et al. 2008), English being the benchmark group.

Tests employ the Heteroskedasticity-consistent covariance matrix estimator 3 (HC3); Variance inflation factor (VIF); Outliers have been defined and excluded using observations for which the standardised residuals lie outside the range of $+/-$ 2 standard deviations. $* * *, * *$ and $*$ indicate statistical significance at the $1 \%, 5 \%$ and $10 \%$ levels, respectively. 